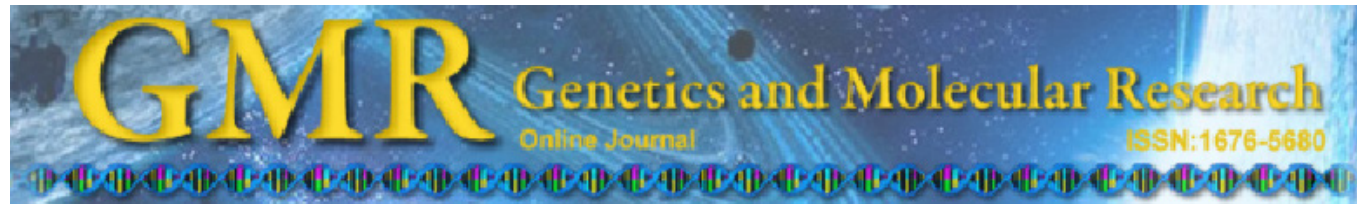

Short Communication

\title{
Sequence analysis of the regulatory region of the TNF-RII gene in Polish Holstein-Friesian cows
}

\author{
A. Stachura, E. Kaczmarczyk and B. Bojarojć-Nosowicz \\ Department of Animal Genetics, Faculty of Animal Bioengineering, \\ University of Warmia and Mazury, Olsztyn, Poland \\ Corresponding author: A. Stachura \\ E-mail: alicja.stachura@uwm.edu.pl
}

Genet. Mol. Res. 12 (2): 1028-1034 (2013)

Received July 6, 2012

Accepted January 17, 2013

Published April 2, 2013

DOI http://dx.doi.org/10.4238/2013.April.2.19

\begin{abstract}
Tumor necrosis factor receptor type II (TNF-RII) is a surface glycoprotein that can form a complex with TNF- $\alpha$ and participate in the body's immune response. Functions of TNF-RII are impaired in the pathogenesis of viral diseases. We analyzed sequences in the regulatory region of the TNF-RII gene in cattle. An attempt was also made to identify mutations that would have the greatest effect on the expression of the TNF-RII gene. Selected fragments of the regulatory region of the TNF-RII gene (5'-flanking region, fragments of intron 1 and 3'-UTR) were sequenced and analyzed. Seven of the 37 analyzed mutations listed in the dbSNP base (NCBI, Gene ID 338033) were confirmed. Three previously unidentified mutations were also discovered: G/A at position -1085 (5'-flanking region), $\mathrm{C} / \mathrm{T}$ at position 6338 and $\mathrm{CA}$ dinucleotide STR [alleles $(\mathrm{CA})_{2},(\mathrm{CA})_{5},(\mathrm{CA})_{7}$ ] at position 16512 (intron 1). Two single nucleotide polymorphisms with potentially the greatest effect on TNF-RII gene expression were identified, at position 16534 in intron 1 (rs42686850) and at position 33102 in the 3 '-UTR (rs136228480). Further study is needed to determine whether these mutations found in the regulatory region influence TNF-RII gene expression, modulate the body's immune response and susceptibility to infections.
\end{abstract}

Key words: TNF-RII; Gene; Polymorphism; Sequence; Mutations; Cattle 


\section{INTRODUCTION}

Tumor necrosis factor-alpha (TNF- $\alpha$ ) is a pleiotropic cytokine that plays a significant role in the body's immune response. TNF- $\alpha$ acts via two functionally independent receptors: type I (TNF-RI) and type II (TNF-RII). TNF-RII expression is limited mostly to hematopoietic cell lines. The structure and functions of TNF-RII are impaired in the pathogenesis of leukemic diseases (Bloomfield et al., 1985; Trentin et al., 1993). The TNF- $\alpha$ /TNF-RII signaling pathway participates in cell processes related to viral infections caused by human T-lymphotropic virus type I (HTLV-I), Epstein-Barr virus (EBV), and human immunodeficiency virus (HIV) (Herbein and O'Brien, 2000). In humans, mutations in the gene encoding TNF-RII contribute to the development of myelopathy caused by HTLV-I (Nishimura et al., 2000). A study of T lymphocytes in human subjects infected with HTLV-I revealed increased expression levels of TNF-RII but not TNF-RI. The study also demonstrated that cells sampled from patients infected with the above virus were less likely to undergo apoptosis induced by TNF- $\alpha$ (Yang et al., 2002). In cattle, the gene encoding TNF-RII has been localized on chromosome 16. It has an estimated length of $33.5 \mathrm{kbp}$, and it comprises 10 exons and 9 introns. The untranslated region (UTR) of the gene has a length of $75 \mathrm{bp}$ from the 5 '-end and $728 \mathrm{bp}$ from the 3 '-end (NCBI Gene ID 338033). There is a general scarcity of published data on functional areas in the regulatory region of the TNF-RII gene in cattle (e.g., promoters, enhancers, and silencers). Numerous mutations have been observed in various regions of the gene (dbSNP), but their contribution to the pathogenesis of bovine disease has not been investigated to date.

It has been suggested that mutations in genes encoding cytokines and their receptors could be responsible for variations in immune response between individuals, and that they could play an important role in susceptibility/resistance to infections (Nishimura et al., 2000; Tsukasaki et al., 2001). Changes in the regulatory sequences of those genes could alter the structure of transcription factor binding sites and influence their expression. Those functionally significant polymorphic loci have been observed in the regulatory regions of genes encoding cytokines, including interleukins $1,6,10,12,13$, and 16 , interferon- $\gamma$, transforming growth factor $\beta$, and their selected receptors (Smith and Humphries, 2008). The aim of this study was to analyze sequences in the regulatory region of the TNF-RII gene in cattle. An attempt was also made to identify mutations with potentially the greatest effect on the expression of the TNF-RII gene. Selected fragments of the regulatory region of the TNF-RII gene were sequenced and analyzed. The present study constitutes the first analysis of the regulatory region of the TNF-RII gene in cattle.

\section{MATERIAL AND METHODS}

The DNA samples analyzed were obtained from 15 Polish Holstein-Friesian cows from a herd in northeastern Poland. Blood was sampled from the mammary vein, and heparin was used as the anticoagulant. Genomic DNA was isolated in accordance with manufacturer recommendations (Epicentre, USA). Ten fragments from the regulatory region of the TNF-RII gene were selected for analysis (Figure 1; reference sequence NC_007314.4, Gene ID 338033, NCBI, USA) on the basis of information about the gene, possible mutations in the gene (dbSNP, NCBI), and the results of bioinformatics sequence analysis - a simulation of transcription factor binding (MatInspector - Genomatix, Germany) and an analysis of interspecies ho- 
mology (BLAST - NCBI; Bio-Edit - Ibis Biosciences, USA). The selected fragments were amplified by PCR, sequenced and compared with the reference genome sequence (RefSeq NC_007314.4, NCBI) using the Bio-Edit software (Ibis Biosciences).

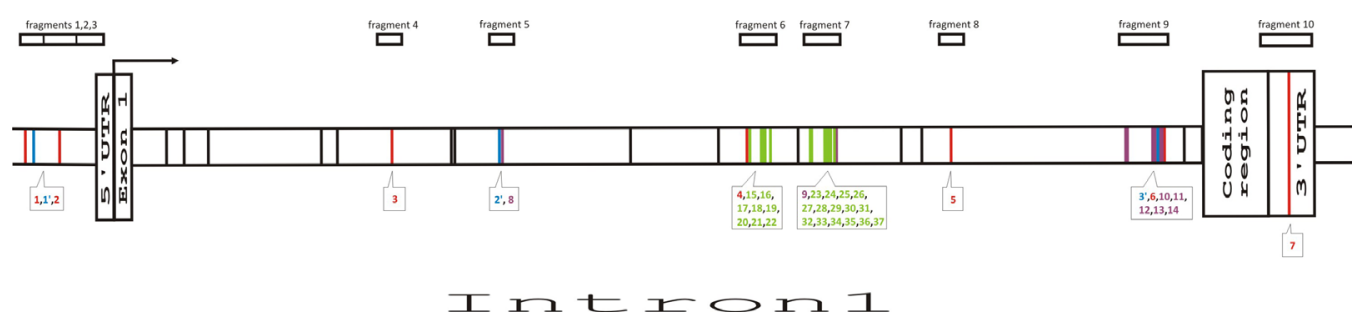

Figure 1. Regulatory region of the TNF-RII gene. The location of the sequenced fragments is shown at the top (numbering is consistent with the data in Table 1). The analyzed mutations were marked in: red = confirmed polymorphic loci; purple $=$ unconfirmed polymorphic loci - monomorphic (allele identical to the reference sequence); green = unconfirmed polymorphic loci - monomorphic (allele different from the reference sequence); blue $=$ mutations discovered in this study (numbering is consistent with the data in Tables 3 and 4).

The primer sequence was determined with the use of the Primer-BLAST (NCBI) program (Table 1). Gene fragments in the 5'-flanking region were amplified in $25 \mu \mathrm{L}$ PCR mix with the composition given in Table 2. The PCR program was as follows: initial denaturation for $30 \mathrm{~s}$ at $98^{\circ} \mathrm{C}$, denaturation for $5 \mathrm{~s}$ at $98^{\circ} \mathrm{C}$, annealing for $5 \mathrm{~s}$ at temperature adjusted for each primer pair (Table 1), extension for $5 \mathrm{~s}$ at $72^{\circ} \mathrm{C}$, and a final extension for $1 \mathrm{~min}$ at $72^{\circ} \mathrm{C}$. The number of PCR cycles varied (Table 1).

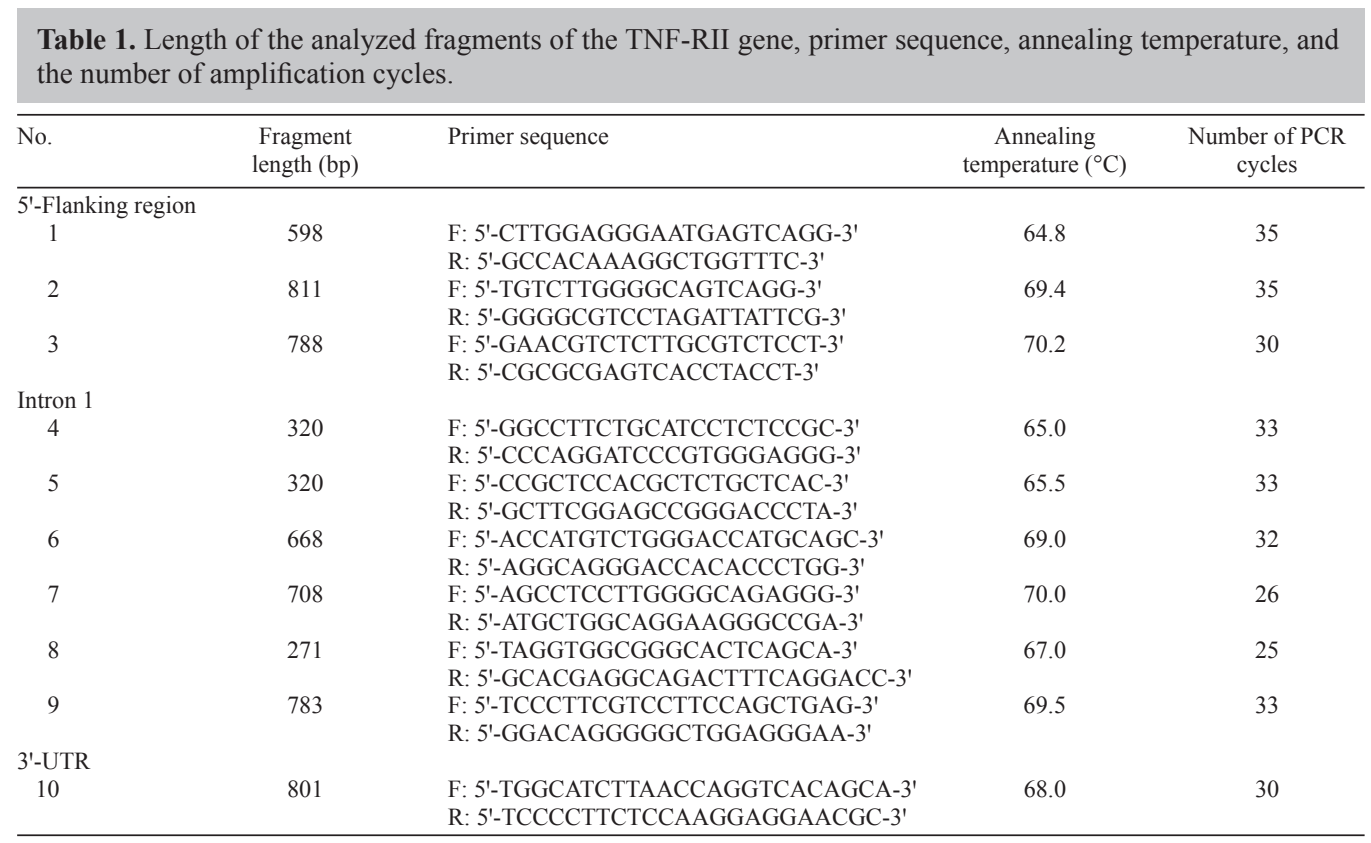




\begin{tabular}{lccc}
\hline $\begin{array}{l}\text { Table 2. Mixture composition in polymerase chain reaction. } \\
\text { Component }\end{array}$ & Initial concentration & Volume per sample $(\mu \mathrm{L})$ & Manufacturer, country of origin \\
\hline Amplification in the 5'-flanking region & & & \\
Phire reaction buffer with $\mathrm{Mg}^{2+}$ & $5 \mathrm{X}$ & 5.0 & Finnzymes, Finland \\
Phire Hot Start II DNA Polymerase & $1 \mathrm{U} / \mu \mathrm{L}$ & 0.1 & Finnzymes, Finland \\
Forward primer & $0.1 \mathrm{M}$ & 0.3 & IBB PAN, Poland \\
Reverse primer & $0.1 \mathrm{M}$ & 0.3 & IBB PAN, Poland \\
dNTPs mix & $10 \mathrm{mM}$ & 1.5 & Epicentre, USA \\
Genomic DNA & $\pm 75 \mathrm{ng} / \mu \mathrm{L}$ & 1.0 & - \\
Distilled water & - & 16.8 & - \\
Amplification in intron 1 and the 3'-UTR & $10 \mathrm{X}$ & & A\&A Biotechnology, Poland \\
Run reaction buffer with Mg ${ }^{2+}$ & $1 \mathrm{U} / \mu \mathrm{L}$ & 1.5 & A\&A Biotechnology, Poland \\
Run polymerase & $0.1 \mathrm{M}$ & 0.7 & IBB PAN, Poland \\
Forward primer & $0.1 \mathrm{M}$ & 0.4 & IBB PAN, Poland \\
Reverse primer & $10 \mathrm{mM}$ & 0.4 & Epicentre, USA \\
dNTPs mix & $\pm 75 \mathrm{ng} / \mu \mathrm{L}$ & 1.5 & - \\
Genomic DNA & - & 2.0 & - \\
Distilled water & & 18.5 & \\
\hline
\end{tabular}

Gene fragments in intron 1 and $3^{\prime}-\mathrm{UTR}$ were also amplified in a $25-\mu \mathrm{L}$ reaction mix with the composition given in Table 2. The following PCR program was used: initial denaturation for $3 \mathrm{~min}$ at $94^{\circ} \mathrm{C}$, denaturation for $30 \mathrm{~s}$ at $94^{\circ} \mathrm{C}$, annealing for $30 \mathrm{~s}$ at temperature adjusted for each primer pair (Table 1), extension for $30 \mathrm{~s}$ at $72^{\circ} \mathrm{C}$, and a final extension for 5 min at $72^{\circ} \mathrm{C}$. The number of PCR cycles is shown in Table 1 . The quality of the PCR products was tested on a $1.5 \%$ agarose gel (Prona, Spain).

The amplified fragments of the TNF-RII gene were sequenced with the use of the Applied Biosystems BigDye ${ }^{\circledR}$ Terminator v3.1 kit (Life Technologies, USA) and the Applied Biosystems 3730xl DNA Analyzer or the Applied Biosystems 3130xl Genetic Analyzer (Life Technologies) supplied by Genomed (Poland). The results were processed using FinchTV (Geospiza, USA) and the BioEdit software (Ibis Biosciences).

\section{RESULTS AND DISCUSSION}

An analysis of sequences in the 5'-flanking region revealed the presence of three SNPs at positions $-641 \mathrm{G} / \mathrm{A},-1085 \mathrm{G} / \mathrm{A}$ and $-1191 \mathrm{C} / \mathrm{T}$ (relative to the transcription start site). Mutations recorded at positions $-641 \mathrm{G} / \mathrm{A}$ and $-1191 \mathrm{C} / \mathrm{T}$ confirmed the data in the NCBI database (rs134099519 and rs110199800, respectively; Table 3), whereas the SNP identified in the present study at position -1085 G/A has not been described in any of the available databases (Table 4). The sequence of the 5'-flanking region with three identified SNPs was deposited in the NCBI database under No. HM989950.

To date, 46 polymorphic loci have been identified in the intron 1 region of the TNFRII gene (dbSNP, NCBI). Thirty-four of these loci were analyzed in our study (Table 3). Four mutations were confirmed: deletion of CAT at position 4583 (rs133292231) and SNPs at positions $10013 \mathrm{C} / \mathrm{T}$ (rs110234068), $13362 \mathrm{G} / \mathrm{A}$ (rs42686852), and $16534 \mathrm{~T} / \mathrm{C}$ (rs42686850). Two previously unidentified mutations were also discovered - SNP at position $6338 \mathrm{C} / \mathrm{T}$ and CA dinucleotide STR (short tandem repeat) at position 16512 (Table 4). The remaining 27 analyzed polymorphic loci catalogued in the NCBI database were identified as monomorphic in this study (Table 3). Twenty-three of these loci had an allele that differed from that in the reference sequence (NC_007314.4) but was consistent with the second allele recorded in dbSNP (Table 
3). The above data can probably be attributed to inter-breed differences in genome sequences investigated by different researchers.

An analysis of the sequence in the 3'-UTR revealed a T/A mutation at position 33102, which was consistent with the sequence listed in the NCBI database (rs136228480) (Table 3).

\begin{tabular}{|c|c|c|c|c|c|c|}
\hline Specification & $\begin{array}{l}\text { Region of the } \\
\text { TNF-RII gene }\end{array}$ & No. & NCBI dbSNP rs & $\begin{array}{c}\text { Allele in reference } \\
\text { sequence* }\end{array}$ & $\begin{array}{l}\text { Allele described } \\
\text { in dbSNP }\end{array}$ & $\begin{array}{l}\text { Allele identified } \\
\text { in this study }\end{array}$ \\
\hline \multirow[t]{2}{*}{$\begin{array}{l}\text { Confirmed } \\
\text { polymorphic loci }\end{array}$} & 5'-flanking region & $\begin{array}{l}1 \\
2\end{array}$ & $\begin{array}{l}\text { rs110199800 } \\
\text { rs134099519 }\end{array}$ & $\begin{array}{l}\mathrm{C} \\
\mathrm{G}\end{array}$ & $\begin{array}{l}\mathrm{C}, \mathrm{T} \\
\mathrm{G}, \mathrm{A}\end{array}$ & $\begin{array}{l}\mathrm{C}, \mathrm{T} \\
\mathrm{G}, \mathrm{A}\end{array}$ \\
\hline & 3'-UTR & $\begin{array}{l}3 \\
4 \\
5 \\
6 \\
7\end{array}$ & $\begin{array}{l}\text { rs133292231 } \\
\text { rs110234068 } \\
\text { rs42686852 } \\
\text { rs42686850 } \\
\text { rs } 136228480\end{array}$ & $\begin{array}{c}\text { CAT } \\
\text { C } \\
\text { G } \\
\text { T } \\
\text { T }\end{array}$ & $\begin{array}{c}-, \mathrm{CAT} \\
\mathrm{C}, \mathrm{T} \\
\mathrm{A}, \mathrm{G} \\
\mathrm{C}, \mathrm{T} \\
\mathrm{T}, \mathrm{A}\end{array}$ & $\begin{array}{c}-, \mathrm{CAT} \\
\mathrm{C}, \mathrm{T} \\
\mathrm{A}, \mathrm{G} \\
\mathrm{C}, \mathrm{T} \\
\mathrm{T}, \mathrm{A}\end{array}$ \\
\hline $\begin{array}{l}\text { Unconfirmed } \\
\text { polymorphic } \\
\text { loci - monomorphic } \\
\text { (allele identical to the } \\
\text { reference sequence) }\end{array}$ & Intron 1 & $\begin{array}{r}8 \\
9 \\
10 \\
11 \\
12 \\
13 \\
14\end{array}$ & $\begin{array}{l}\text { rs } 137006077 \\
\text { rs } 135997227 \\
\text { rs } 137330975 \\
\text { rs } 133763039 \\
\text { rs } 137804743 \\
\text { rs } 42686851 \\
\text { rs } 134307832\end{array}$ & $\begin{array}{c}\mathrm{T} \\
\mathrm{T} \\
\mathrm{G} \\
\mathrm{A} \\
\mathrm{A} \\
\mathrm{A} \\
\text { TGCACACA }\end{array}$ & $\begin{array}{c}\mathrm{C}, \mathrm{T} \\
\mathrm{G}, \mathrm{T} \\
\mathrm{A}, \mathrm{G} \\
\mathrm{A}, \mathrm{G} \\
\mathrm{A}, \mathrm{G} \\
\text { A,G } \\
\text {-,TGCACACA }\end{array}$ & $\begin{array}{c}\mathrm{T} \\
\mathrm{T} \\
\mathrm{G} \\
\mathrm{A} \\
\mathrm{A} \\
\mathrm{A} \\
\text { TGCACACA }\end{array}$ \\
\hline $\begin{array}{l}\text { Unconfirmed } \\
\text { polymorphic } \\
\text { loci - monomorphic } \\
\text { (allele different from } \\
\text { the reference sequence) }\end{array}$ & Intron 1 & $\begin{array}{l}15 \\
16 \\
17 \\
18 \\
19 \\
20 \\
21 \\
22 \\
23 \\
24 \\
25 \\
26 \\
27 \\
28 \\
29 \\
30 \\
31 \\
32 \\
33 \\
34 \\
35 \\
36 \\
37\end{array}$ & $\begin{array}{l}\text { rs } 135613221 \\
\text { rs } 109455854 \\
\text { rs } 109908622 \\
\text { rs } 135480062 \\
\text { rs } 133771406 \\
\text { rs } 137735044 \\
\text { rs } 134729420 \\
\text { rs } 110995715 \\
\text { rs } 136260851 \\
\text { rs } 137226282 \\
\text { rs } 133265347 \\
\text { rs } 110673758 \\
\text { rs } 110614065 \\
\text { rs } 109313337 \\
\text { rs } 137581261 \\
\text { rs } 134278794 \\
\text { rs } 136653021 \\
\text { rs } 135410591 \\
\text { rs } 133294803 \\
\text { rs } 134486761 \\
\text { rs } 132746733 \\
\text { rs } 135815823 \\
\text { rs } 109460469\end{array}$ & $\begin{array}{l}\text { G } \\
\text { T } \\
\text { T } \\
\text { T } \\
\text { C } \\
\text { C } \\
\text { C } \\
\text { A } \\
\text { A } \\
\text { A } \\
\text { A } \\
\text { A } \\
\text { A } \\
\text { A } \\
\text { A } \\
\text { A } \\
\text { A } \\
\text { A } \\
\text { A } \\
\text { A } \\
\text { A } \\
\text { A } \\
\text { A }\end{array}$ & $\begin{array}{l}-, \mathrm{G} \\
\mathrm{T}, \mathrm{C} \\
\mathrm{T}, \mathrm{C} \\
\mathrm{T}, \mathrm{A} \\
\mathrm{A}, \mathrm{C} \\
\mathrm{A}, \mathrm{C} \\
\mathrm{A}, \mathrm{C} \\
\mathrm{A}, \mathrm{G} \\
\mathrm{A}, \mathrm{C} \\
\mathrm{A}, \mathrm{C} \\
\mathrm{A}, \mathrm{C} \\
\mathrm{A}, \mathrm{T} \\
\mathrm{A}, \mathrm{G} \\
\mathrm{A}, \mathrm{C} \\
\mathrm{A}, \mathrm{C} \\
\mathrm{A}, \mathrm{C} \\
\mathrm{A}, \mathrm{T} \\
\mathrm{A}, \mathrm{C} \\
-, \mathrm{A} \\
\mathrm{A}, \mathrm{C} \\
\mathrm{A}, \mathrm{T} \\
\mathrm{A}, \mathrm{T} \\
\mathrm{A}, \mathrm{T}\end{array}$ & $\begin{array}{l}- \\
\mathrm{C} \\
\mathrm{C} \\
\mathrm{A} \\
\mathrm{A} \\
\mathrm{A} \\
\mathrm{A} \\
\mathrm{G} \\
\mathrm{C} \\
\mathrm{C} \\
\mathrm{C} \\
\mathrm{T} \\
\mathrm{G} \\
\mathrm{C} \\
\mathrm{C} \\
\mathrm{C} \\
\mathrm{T} \\
\mathrm{C} \\
- \\
\mathrm{C} \\
\mathrm{T} \\
\mathrm{T} \\
\mathrm{T}\end{array}$ \\
\hline
\end{tabular}

*Reference sequence: NC_007314.4 (NCBI).

Table 4. Newly discovered mutations.

\begin{tabular}{lcccc}
\hline Region of the TNF-RII gene & No. & Nucleotide position* & Allele in reference sequence** & Allele identified in this study \\
\hline 5'-flanking region & $1^{\prime}$ & -1085 & $\mathrm{G}$ & $\mathrm{G}, \mathrm{A}$ \\
Intron 1 & $2^{\prime}$ & 6338 & $\mathrm{C}$ & $\mathrm{C}, \mathrm{T}$ \\
& $3^{\prime}$ & 16512 & $(\mathrm{CA})_{11}$ & $(\mathrm{CA})_{2},(\mathrm{CA})_{5},(\mathrm{CA})_{7}$
\end{tabular}

*Relative to the transcription start site. ${ }^{* *}$ Reference sequence: NC_007314.4 (NCBI).

On the basis of the sequence results, we determined the number of animals with the mutated allele at the recorded polymorphic loci (Table 5). The above data and the results of a 
bioinformatics analysis of the sequenced regions (unpublished data) supported the identification of SNPs with potentially the greatest influence on the expression of the TNF-RII gene. Mutations were observed at position 16534 (rs42686850) in intron 1 and at position 33102 (rs136228480) in the 3'-UTR. The remaining SNPs seemed to have an insignificant effect on TNF-RII gene expression because they failed to meet at least two of the three adopted criteria: a large group of animals with the mutated allele, a possible effect on binding of important transcription factors, and high interspecies homology in the regions of the noted mutations.

Table 5. Number of animals with mutated alleles in recorded polymorphic loci.

\begin{tabular}{lcc}
\hline Nucleotide position in the TNF-RII gene* & dbSNP symbol & Number of animals with mutated allele $(\mathrm{N}=15)$ \\
\hline$-641 \mathrm{G} / \mathrm{A}$ & rs 134099519 & 3 \\
$-1191 \mathrm{C} / \mathrm{T}$ & rs 110199800 & 3 \\
$-1085 \mathrm{G} / \mathrm{A}$ & None & 5 \\
$4583-/ \mathrm{CAT}$ & rs 133292231 & 3 \\
$10013 \mathrm{C} / \mathrm{T}$ & rs 110234068 & 13 \\
$13362 \mathrm{G} / \mathrm{A}$ & $\mathrm{rs} 42686852$ & 3 \\
$16534 \mathrm{~T} / \mathrm{C}$ & rs 42686850 & 13 \\
$6338 \mathrm{C} / \mathrm{T}$ & None & 3 \\
$16512(\mathrm{CA})_{11}$ & None & 15 \\
$33102 \mathrm{~T} / \mathrm{A}$ & rs 136228480 & 13 \\
\hline
\end{tabular}

*Based on reference sequence: NC_007314.4 (NCBI).

An analysis of the sequence covering the SNP at position 16534 in intron 1 (rs42686850) revealed allele-specific binding of transcription factors from the E2F family. Those proteins play a key role in regulating the cell cycle and cell proliferation, and they are elements of the TNF- $\alpha /$ TNF-R signaling pathway. Sequence changes in the intron 1 region can affect the binding capacity of those proteins and, consequently, the expression of the TNF-RII gene. E2F transcription factors regulate the expression of numerous genes that participate in cell proliferation (Müller and Helin, 2000). They control the cell cycle, and E2F transcription factors with impaired function are observed in various malignancies. The E2F-1 transcription factor is also capable of inducing apoptosis (Phillips et al., 1999). It has been suggested that the factor in question protects the cell against pathogenic proliferative signals. This property could be an element of a specific mechanism protecting the body against malignant cell transformation (Phillips et al., 1999). Cells where the E2F-1 factor is overexpressed are more sensitive to TNF- $\alpha$ and are more likely to undergo apoptosis (Phillips et al., 1999). Cell apoptosis induced by E2F1 may also be suppressed by viral apoptosis inhibitors (Thome et al., 1997; Zhou et al., 1997).

The second polymorphic locus with a potential effect on TNF-RII gene expression was the SNP at position 33102 in the 3'-UTR (rs136228480). Polymorphism in the above area has been found to be correlated with the expression of human cytokine-encoding genes (Bensen et al., 2003; Danckwardt et al., 2008). It is believed that 3'-UTR mRNA could control nuclear export, polyadenylation, and the rate of mRNA translation and degradation. Modifications in the gene region encoding 3'-UTR mRNA could alter its functioning (Conne et al., 2000). The 3'-UTR transcribed from a single mutated allele could have a dominant negative effect by disrupting the transport of trans-acting factors and other regulatory proteins in the cell. The 3'-UTR is considered to be one of the key elements regulating gene expression (Conne et al., 2000). To date, more than 50 polymorphic loci have been identified in the 3'-UTR of the human TNF-RII gene (NCBI Gene ID 7133). At least three of those loci are believed to have a 
significant influence on gene expression levels (Puga et al., 2005). In this study, only a single mutation was noted in the 3'-UTR, but its effect on the expression of the TNF-RII gene in cattle has not been investigated to date.

The present study analyzed selected fragments of the regulatory region of the TNFRII gene in Polish Holstein-Friesian cattle. Our results confirmed the presence of 7 of the 37 analyzed mutations that are catalogued in the dbSNP database (NCBI). Three previously unidentified mutations were also noted: G/A at position -1085 (5'-flanking region), C/T at position 6338 and CA dinucleotide STR [alleles $(\mathrm{CA})_{2},(\mathrm{CA})_{5}$ and $(\mathrm{CA})_{7}$ ] at position 16512 (intron 1). Two SNPs with potentially the greatest effect on TNF-RII gene expression were identified: at position 16534 in intron 1 (rs42686850) and at position 33102 in the 3'-UTR (rs136228480). The mutation in intron 1 can disrupt binding of E2F transcription factors that regulate the expression of cell proliferation genes, possibly also the TNF-RII gene. The T/A mutation in the gene region encoding 3'-UTR mRNA can induce changes in the function of this element, which plays a vital role in gene expression control. Further study is needed to determine whether the mutations identified in the regulatory region influence TNF-RII gene expression and modulate the body's immune response and susceptibility to infections.

\section{REFERENCES}

Bensen JT, Langefeld CD, Li L, McCall CE, et al. (2003). Association of an IL-1A 3'UTR polymorphism with end-stage renal disease and IL-1 alpha expression. Kidney Int. 63: 1211-1219.

Bloomfield CD, Garson OM, Volin L, Knuutila S, et al. (1985). t(1;3)(p36;q21) in acute nonlymphocytic leukemia: a new cytogenetic-clinicopathologic association. Blood 66: 1409-1413.

Conne B, Stutz A and Vassalli JD (2000). The 3' untranslated region of messenger RNA: A molecular 'hotspot' for pathology? Nat. Med. 6: 637-641.

Danckwardt S, Hentze MW and Kulozik AE (2008). 3' end mRNA processing: molecular mechanisms and implications for health and disease. EMBO J. 27: 482-498.

Herbein G and O'Brien WA (2000). Tumor necrosis factor (TNF)-alpha and TNF receptors in viral pathogenesis. Proc. Soc. Exp. Biol. Med. 223: 241-257.

Müller H and Helin K (2000). The E2F transcription factors: key regulators of cell proliferation. Biochim. Biophys. Acta 1470: M1-12.

Nishimura M, Maeda M, Matsuoka M, Mine H, et al. (2000). Tumor necrosis factor, tumor necrosis factor receptors type 1 and 2, lymphotoxin-alpha, and HLA-DRB1 gene polymorphisms in human T-cell lymphotropic virus type I associated myelopathy. Hum. Immunol. 61: 1262-1269.

Phillips AC, Ernst MK, Bates S, Rice NR, et al. (1999). E2F-1 potentiates cell death by blocking antiapoptotic signaling pathways. Mol. Cell 4: 771-781.

Puga I, Lainez B, Fernández-Real JM, Buxadé M, et al. (2005). A polymorphism in the 3' untranslated region of the gene for tumor necrosis factor receptor 2 modulates reporter gene expression. Endocrinology 146: 2210-2220.

Smith AJ and Humphries SE (2009). Cytokine and cytokine receptor gene polymorphisms and their functionality. Cytokine Growth Factor Rev. 20: 43-59.

Thome M, Schneider P, Hofmann K, Fickenscher H, et al. (1997). Viral FLICE-inhibitory proteins (FLIPs) prevent apoptosis induced by death receptors. Nature 386: 517-521.

Trentin L, Zambello R, Agostini C, Siviero F, et al. (1993). Expression and functional role of tumor necrosis factor receptors on leukemic cells from patients with type B chronic lymphoproliferative disorders. Blood 81: 752-758.

Tsukasaki K, Miller CW, Kubota T, Takeuchi S, et al. (2001). Tumor necrosis factor alpha polymorphism associated with increased susceptibility to development of adult T-cell leukemia/lymphoma in human T-lymphotropic virus type 1 carriers. Cancer Res. 61: 3770-3774.

Yang YC, Hsu TY, Lin RH, Su IJ, et al. (2002). Resistance to tumor necrosis factor-alpha-induced apoptosis in human T-lymphotropic virus type I-infected T cell lines. AIDS Res. Hum. Retroviruses 18: 207-212.

Zhou Q, Snipas S, Orth K, Muzio M, et al. (1997). Target protease specificity of the viral serpin CrmA. Analysis of five caspases. J. Biol. Chem. 272: 7797-7800. 